\title{
Democratization and Women’s Political Space in Nigeria: A Critical Appraisal
}

\author{
Emma Chukwuemeka, Ph.D \\ Senior Lecturer, Public Administration/Coordinator, Postgraduate \\ Studies, Faculty of Management Sciences, Nnamdi Azikiwe University, \\ Awka, Nigeria \\ Tel: +2348060967169Ｅ-mail: hrvkonsult@yahoo.com
}

Sunday C.Eze

Business and Management Research Institute

University of Bedfordshire, UK

eze.sunday2010@gmail.com

Received: June 16, 2011 Accepted: June 29, 2011 DOI: 10.5296/jpag.v1i1.746

\begin{abstract}
The study investigates the extent women participate in politics in Nigeria. Abia and Imo states were closely studied. Two hypotheses were formulated. The instruments used for data collection were questionnaire, interview and focus group discussion. A total of 354 copies of questionnaire were distributed, out of this number, 349 copies were completed and returned by the respondents. Z-test statistical tool was used to analyze the data, Based on the analysis, the major findings revealed that violence against women deter women from getting actively involved in politics in Nigeria. Also culture and traditional ethos prevent the advancement of women in politics also. Based on these findings, the following recommendations among others were proffered: Political mobilization should be carried into the villages to sensitize the women on the need to get involved in politics. More so new laws should be enacted on political thuggery and violence. They should be pursued vigorously to curb the high level of violence meted out to women by their male political counterparts in Nigeria.
\end{abstract}

Keywords: Politics, women, violence, monetization, cultural ethos, Nigeria. 


\section{Introduction}

The role of women in national development need not be over-emphasized. The United Nation's declaration that the full and complete development of any country requires the maximum participation of women in all fields has proved to be a catalyst to the prominence women development has come to acquire in recent times. World governments, international agencies, non-governmental organizations and other key policy makers have all stressed the need for women to adequately participate in the economy, government and overall growth of their countries.

Even in traditional societies where women were accorded domestic recognition, women had, at one time or the other, taken time out to engage in activities relevant to the stability and continuous existence of their various communities. Women had also exhibited appreciable managerial and organizational skills in their roles as mothers, homemakers, character molders and sustainers of humanity. Their supportive roles through engagement in pottery, weaving, spinning and other socio-economic activities were indispensable to the existence of their families and societies by extension; Chinsman (2005) summarizes the role of women thus: "women constitute the foundation of any society. One cannot talk about society without talking about the family, nor can one talk about the family without talking about the women... their ingenuity serves and sustains the family”.

Some exceptional women had, at one time or the other, exhibited great knowledge of leadership and statesmanship across the globe. History testifies to the prowess of women like Nigeria's Queen Amina of Zaria, Emotan of Benin, Indira Ghandi of India, Golda Meir of Israel, Benazir Bhutto of Pakistan, Margaret Thatcher of Britain just to mention a few. These skills and ability have grown astronomically in recent times given the improved educational and employment opportunities. Names like Professor Grace Aalele-Wiliams, Dr. Tokunbo Awolowo-Dosume, Professor Ndi Okereke-Onyiuke,Dr. Ngozi Okonjo-Iweala and so on are pointers to the high level of achievement of the Nigerian women.

The Nigerian government equally provided some stimulus to the education and self-development of women, knowing that an educated and economically independent woman is an asset to her home and the Nation. Women are encouraged, in cognizance of their abilities, to participate actively in the political affairs of their country. They are persuaded to engage in party politics, seek election into political offices and aspire to occupy leadership positions in their respective parties. Women are also expected to be sensitive to governmental policies, react positively to national issues and make significant contributions to national issues and make significant contributions to nation-building strategies. Unfortunately, the response has been low. Women have continued to be audibly and visibly silent on key national issues. Only a negligible few have come out to participate politically at the transitional and gladiatorial levels (Ukor, 2008).

\section{Statement of the problem}

It is not in doubt that women are marginalized in political, economic and decision making processes. In the opinion of Ugochukwu (2009), women are marginalized and grossly 
unrepresented in the area of public life where important decisions which affect their lives are taken. The political world is essentially male dominated in spite of the increased participation of women in politics in recent years. Bryan (2005) argues that women in the political arena were abysmally low world over. Thus the problem is not peculiar to Nigeria. He further argues that in Bangladesh only $106 \%$ of the women population participates in politics, Bhutan records 5.7\%, India 7.6\%, the Maldives 5\%, Nepal 3.5\%.

An examination of the political development in Nigeria suggests that the role of women in politics has been very minimal. For instance, there was no single representation of women in the forty nine 'wise-men' that drafted the Nation's 1979 constitution despite the large number of professional women in Nigeria. On party basis the proportions holding top executive posts were very negligible (Edu, 2008). In ministerial appointments, only a success of $10 \%$ was recorded in May 2007 (Ugwu, 2007). Each state in Nigeria has ensured the appointment of only one woman as a commissioner. Marginalization of women is not a new phenomenon in Nigeria; Fubara (1995) observes that the first republic political parties in Nigeria were dominated by men. For instance, membership of the National Council of Nigeria and Cameroon and the Northern Element Progressive Congress recorded 64 males and 7 males for NCNC and 57 males and 5 females for NPC respectively. In the legislative assembly, out of 53 people only 1 was a female. Fubara (1995) sharply concludes that the role of women in the political organization of Nigeria illustrates that women have been deprived of responsibilities that ought to be largely theirs.

In the second republic, there was also one woman senator (Ugwu, 2001). In Abia and Imo states (the study area), out of 38 local government executive chairmen, none is a woman, none is a deputy chairman. Out of 68 local government supervisors only 20 were women; out of 400 councilors only 15 were women; out of 20 commissioners, only 5 were female (Chukwuemeka, 2009). Ogbe (2008) contends that over 98\% of elective offices in Nigeria are occupied by men. Thus the United Nation's recommendation that at least $30 \%$ of political office should be occupied by women is not yet attained in Nigeria.

\section{Literature Review}

\subsection{Political Participation}

In all political systems, the need exists for the citizenry, both male and female, to participate in the act of governance. This could be achieved through effective political participation. One of those concepts in the social sciences that has been defined in several ways and given different meanings. Perhaps, a consideration of some of these definitions will help us in arriving at a conclusion as to the basic meaning of political participation. Norman and Verba (1975) have defined political participation as consisting of those legal activities by private citizens which are more or less directly aimed at influencing the selection of governmental personnel and or the actions they take. Huntington and Dominiquez (1975) defined political participation simply as 'activity of private citizens designed to influence government decision making.

Thus political participation can be either direct, in the sense of being involved in government 
or indirect by observing and making contribution to the act of governance.

We can therefore conclude as follows:

(a) Political participation is concerned with influencing the composition and conduct, personnel, policies, of government.

(b) Political participation is not limited to voting at elections but includes many other ways in which citizens try to influence governmental decisions.

(c) For conceptual clarity, political participation is often defined to include the activities of private citizens only, and to exclude the behaviors of government and party officials who are more or less continuously involved in politics, in other words, these officials are regarded as the object rather than the source of political participation

(d) Although, theoretically, political participation can include both legal and illegal attempts to influence governmental decisions, behaviouralist, and other analysis usually focus only on legal forms of participation and tend to treat as 'abnormal' such illegal and often violent forms of participation as riots and assassinations.

(e) Participation is usually regarded as a desirable or positive process. It has been seen as a civic duty, as a sign of political health, as the best method of ensuring that one's private interests are not neglected and as a sine qua non of a democracy.

(f) Finally, political participation is a concrete activity or behavior and not simply a psychological orientation or disposition. While psychological orientation may provide the basis for political participation, behaviouralists are interested more in the actual behaviour of citizens in attempting to influence government than in the psychological sources of that behaviour (Thompson, 2001).

Ogunna, (2006) argues that political participation is an indispensable element of democracy. The participation of the people ( male and female) is a sine qua non of good government. It is also a healthy action, a civic duty and an essential ingredient of democracy. Nwankwo (2009) contends that participation should not end in voting or political campaigns but should cut across other aspect of political processes. There are always basic requirements of political participation. The requirements are fully explained by Hills ( 2010), Ude (1999) and Ambe 
(2007). They include:

(a) Making sure that your name is on the register of people to vote during elections

(b) Voting during elections.

(c) Belonging to political party e,g. one can form a party or join others

(d) Standing for election into offices. Examples of such offices include:

- political party offices

- local government chairmanship

- councillorship

- house or representative, senate, governorship, president etc.

(e) Taking interest in public matters. This can be by knowing what the government is doing and planning, what its policies are, and what people think of these policies

(f) Defending the right of citizens by actions, speaking out against corruption, bad government and injustice.

\subsection{Levels of political participation}

Political participation can take a wide variety of forms and can occur at various levels. Getting involved in political participation entails costs in time, energy and resources (Gorsuch, 2000). Yet individuals and groups differ in the amount of resources that they are able or willing to devote to political participation. Thus, while most people engage in the kind of political participation or another, not all persons are able to participate in politics to the same degree (Mcphail, 2009) In other words, some people participate more extensively and effectively in politics than other people. Malbraith (1990) identified three levsls of political participation as:
(a) the spectator level
(b) the transitional level
(c) and the gladiatorial level

\subsubsection{Spectator level of participation}

The following activities are performed at the spectator level. They include:
(a) voting
(b) initiating a public discussion
(c) attempting to influence another into voting in a certain way
(d) wearing a party badge or displaying a party sticker 
Quite obviously, the activities identified above entail relatively little costs in time, energy and resources. Consequently, many people are able to participate at this level of politics than either of the other two levels. In many countries some people do not get involved in politics even at the spectator level. These are the apathetic that do not want to participate in politics at all, and are almost totally unaware of the political world around them. However, the Nigerian case is that of low participation, especially among women

(Ugwueze, 2010).

\subsubsection{Transitional level of participation}

The following activities, according to Brian (2005) are performed at the transitional level. They include:

(a) Attending political meeting or rallies

(b) Making some monetary contribution to a campaign

(c) Contracting a public official or political leader

Activities at this level require more costs in time and resources than those at the spectator level. Activities at this level are referred to as transitional because of the general tendency for participants at this level either to descend to spectator activities or to ascend to gladiatorial activities (Anderson, 2008).

\subsubsection{Gladiatorial level of participation}

Political participation at this level includes:

(a) holding a public or party office

(b) being a candidate for office

(c) soliciting or appealing for party funds

(d) attending a caucus or strategy meeting

(e) contributing time or other resources in a campaign

Activities at this level are more expensive, but most effective forms of political participation.

Onah (1997) gives broad classifications of the electorate: Non participants are those who lack total interest. They do not even possess voter's card. Participants she categorizes into two: the active participants and passive participants. The passive participant knows the names of political parties and can identify their symbols. His participation is most times limited to voting. The active participant attend political rallies, takes part in political campaigns, contributes financially and materially to the success of the party, he identifies himself with and stands for an election and may hold political and executive positions.

For political participation to be effective the following conditions have to be met: 
(a) There must be accurate information and data on government operations

(b) There must be effective political mobilization by designated agencies

(c) The polity must be devoid of intimidation/thuggery and cumbersome political arrangement

(d) The electoral system should be free and fair without cumbersome process

(e) Adequate resources at the disposal of the citizenry to enable them participate in politics.

(f) Citizens should believe that their opinion on national issues influence governmental decisions and actions; that government operations have their interest at heart.

\subsection{Women and political participation in Nigeria}

Several views have been expressed by academics, researchers, writers and women leaders about the state (level) of political participation by Nigerian women. Some see their participation as encouraging, while others do not Ogbenna (2008) sees the level of women participation in politics as encouraging. This view, he supports by drawing a comparison between the number of female members in the 1979 National Assembly with the number in 1983. While there were 6 female law maters in 1979, the number rose to 8 in 1983 Between 1999-2010 the number of women in political position have improved tremendously. Whereas they constituted $0.66 \%$ of House in 1979, they increased to $1.7 \%$ in 1983 . And from 1999-2010 women constituted 30\% of the members of the two chambers in the federal house (Ugwoke, 2011). Njom (2008) referred to the election of two female deputy governors for Cross-River and Lagos states in 1992, Anamabra State in 2007 as evidence of the height women have attained in their political struggle. He cited further examples with female political party leadership in three states (Lagos, Plateau and Benue states), high political and social awareness levels in the Nigerian women even in the Northern Nigeria where religious doctrines hamper women empowerment and development. The election of two female councilors in the Northern Nigeria in 1999 and the emergence of Mrs Titi Ajanaku as a Local Government Chairman during the Babangida's regime in 1992 were clear evidence that women participation in politics is improving (Eze, 2009).

These facts appear to place women high on the political scene. They also painted encouraging pictures of women in political participation. The truth remains that women leaders, activists and scholars have continued to bemoan this insignificant level of women participation in politics. Bolanle Awe, a former Chairperson of the National Commission for Women argues Uzochukwu (2008) at the moment, are excluded from decision-making in all matters affecting their lives. Adefarasin, (2009) says that the only way to address this social injustice is by allowing women to participate in politics. Ntunde (1999) also decries the low political status of the Nigerian women. She talks about the low female representation in the constitutional conferences, the political Bureau, National Electoral commission and other key transition agencies. She laments that issues affecting women were never tabled for deliberation in the constitutional conference. No Nigerian woman was appointed into the 
National Electoral Commisionershp and by this act women were left out of this important political post and getting involved in the political process.

Women marginalization in Nigerian politics is directly related to the issue of poverty. The 1995 human development report of the UN maintained that $70 \%$ of the total world population are women, and that 'poverty has a woman's face' (Harris, 2006). The 1991 population census estimates that the 31 million rural women in Nigeria, 16 million live below the nationally defined poverty lines, The negative impact of poverty on the advancement of women in Nigeria led to their marginalization in decision making capacities, poor appreciation of their contribution in the national economy, poor health, illiteracy, and lack of educational opportunity (Oloaye, 2008).

In the economic point of view, sexual division of labour deprived women of their economic status and led to their subsequent state of penury.. Some researchers like Ibiam,, 2005), Olori (2009) and Ezugwu (2004) have equally blamed colonialism; maintaining that colonial employment opportunities were mainly for men (e.g. railway construction, court messengership. Traditional female midwives lost their jobs to European clinics and maternity homes. Only men were engaged in the new cash crop production while cocoyam, cassava and live stock (originally produced by women) ceased to be a measure of social wealth (Ibiam, 2005).

Monsen (2001) lends weight to this economic marginalization of women. According to her, modernization of agriculture altered division of labour and increased women's dependent status and work load as women lost control over resources such as land and access to new technology. Yet women earn $10 \%$ of the world's income and $1 \%$ of property and produce as much as $80 \%$ of food in Africa (Red, 2004). Ede (2008) also condemn the sex typing of certain occupation as males as well as the unseating feeling with both the private and public sectors that women cannot combine effectively work-place and household to a limited access to means of production, exercising very low levels of ownership of control over modern industries. Commercial and service activities. Monsen (20011) further goes on to explain the forms which economic marginalization of women takes:

(a) Prevention of women from entering some specific types of employment on the premise of physical weakness, moral danger or lack of special facilities for the female worker.

(b) Concentration of female employment in the informal sector where they work for longer hours, get the lowest pay and are insecure.

(c) Subtle feminization and low status of certain jobs brought about by the fact that majority of workers in that profession are women.

(d) Economic inequality brought about by occupational differentiation resulting 
in low wages, poor working condition, inequality of fringe benefits, etc. The

general employment situation force women to accept jobs for which they are

under utilized and under paid (Ogu, 2005).

The problem of gender inequality also takes sociological dimension. Kedly (2006) identifies some of the sociological variables as religious affiliation, ethnicity, socio-economic status and educational level as factors that can inhibit or promote the case of women mobility into public or political realms. Wambia (2006) sees the problem of socialization, attitudinal obstacles to participation and advancement by women, aspects of felt marginalization in the feelings and behavior of women in politics which are related to sex-role socialization as the key factors constraining women from active political participation.

Chukwuemeka (2009) sees strong sense of the importance of and distribution between men and women's traditional roles and what is the accepted behavior, as restricting factors to women development. The result is women being content with remaining as house wives and mothers while they make the family and communities cultures of their lives.

The gender concept of roles and relationship between males and females has been condemned. Nwosu (2007) is of the opinion that gender inequality between men and women has led to negative stereotypes and perception of women, resulting in socio-economic and legal impediments against women. It is pertinent to remark that gender inequality originates from the family during socialization. Thus in the family, boys role are seen as instrumental more serious role of providing for sustenance and security on the family while girls' role are classified as 'expensive' cooking for and the general care of the household. In a typical Nigerian family certain behavior patterns are labeled feminine or masculine, parental preference for male children, men's authority symbol in the famly and so on.

Ike (2006) has also identified retrogressive traditional practices, religious indoctrination, education, cultural and societal barriers, economy/unemployment, language roles, the law and human rights as some of the prejudices militating against acquisition of political power by women.

\section{Objectives of the Study}

(a) To identify the factors responsible for the failure of women to participate effectively in politics in Nigeria especially in Abia and Imo states

(b) To identify the levels of political mobilization of women in Nigeria

(c) To examine the level of participation of women in politics in Abia and Imo States of Nigeria 


\section{Theoretical Foundation}

This paper draws on 'group theory. The intellectual roots of group theory is based on the doctrines of pluralism as developed by a number of early twentieth century English writers, particularly John Figgis, Maithland and G. Cole (Varma, 1975). With the failure of the elite theory, the attention of the political scientists was turned to pluralist model in which power, instead of being concentrated in the hands of a group or class, is treated as diffused among many interest groups competing with each other for power. The origins of the group in its present form go back to Author Bentley (1925). But the theory was subsequently forgotten till it was revived in the fifties and sixties by Daniel Truman (1953), Robert Dahl (1961), Grant McConnel (1966), Theodore J. Lewis (1971) and other writers, as a possible basis of the theory of politics.

Bentley, to whom behavioralism is generally traced, while trying to highlight the importance of group in politics was of the view that the raw material we study (in politics) is never found in one man by himself, it cannot even be stated by adding man to man. It must be taken as it comes in many men together. He argues that society, nation, government legislation, politics, and administration all are made up of 'group of men' each group cutting across many other. These according to him, are in a state of perpetual interaction with each other, and politics consisted in the shunting by some men of other men's conduct along changed lines, the getting of forces to overcome resistance to such alternations or the disposal of one grouping of forces by another grouping.

Bentley, cited in Varma (1975), conceived of the group as a mass of activity and not a collection of individuals. group was defined by him as 'a certain portion of the men of a society, taken, however, not as a physical mass cut off from the masses of men, but as a mass (of) activity, which do not preclude the men who participate in it from participating likewise in many other group activities. A group, therefore, he pointed out, represented a pattern of process rather than a static form, and as such could emerge only when the interactions among its individual members were both relatively frequent and sufficiently patterned to produce directional activity. A genuine group, therefore, was different from a co-incidental collection or a categoric group. The fact that the same individual can belong to various groups also makes it clear that the activity particularly to group was more important than its structural composition.

The group theory leads logically to a particular concept of social system and of political behavior. The society itself, as Bentley writes, is 'nothing other than the complex mosaic of groups'. Truman, cited in Varma (1975), another leading group theorist, argues that it is through the social system that the various groups seek to realize or maximize their interests, the society being 'a single universe of group which combine, break, federate and form coalitions and constellations of power in a flux of restless alterations' and is kept going by 'the push and resistance between groups' The main thrust of group theory, as envisioned by Bentley is that political power should be dispersed and not to be concentrated in a particular secondly, group theory as a pluralistic approach to politics, advocates for 'balance of power' 


\section{Justification of group theory to the study}

Group theory is not only necessary but indispensable in our examination of women and politics because it is group consciousness and selfishness that make the male politicians to look upon their female counterparts as 'ill-fitted' for political positions. To ensure that their views hold, they tend to use all forces within their disposal to frighten the female groups out of their wits. Secondly, it explains the importance of pluralism in politics. It is in agreement with the basic principles of democracy which include equal participation in political process and popular opinion.

Based on the theory, the following hypotheses were formulated to guide the study:

(1) The inability of the government and non-governmental mobilization agencies to articulate effective political mobilization programs have impaired women political participation in Abia and Imo states of Nigeria.

(2) The political violence impairs women's involvement in politics.

\section{Methodology}

The research is descriptive and the design adopted is sample survey. The date used in the study were collected from two principal sources - primary and secondary sources. Instruments used were questionnaire, focus group discussion, face to face interview, journals, books and internet sources.

\subsection{Population}

The research population consisted of all women between the ages of 18 and 60 in Umuahia and Owerri metropolis that have a minimum of West African School Certificate or its equivalent. Thus the total population of Umuahia is 2150, while Owerri is 1839 bringing the total population to 3118 .

\subsection{Sample size}

In selecting the sample size we adopted this formula:

$$
\begin{aligned}
\mathrm{N} & =\frac{\mathrm{N}}{1+\mathrm{N}(\mathrm{e})^{2}} \\
\mathrm{n} & =\frac{3118}{1+3118(0.05)^{2}} \\
& =\frac{3118}{1+7.80 \text { (approx) }}
\end{aligned}
$$




\subsection{Sampling Technique}

Multi-stage sampling technique was adopted. Precisely 2-stage sampling technique was used. In the 1-stage the population was stratified to obtain uniformity among the highly educated and poorly educated women. In the 2-stage simple random sampling was used to select the number of women who fell in the sample frame.

\section{Data Analysis}

Out of 354 questionnaires distributed, 349 were returned (243 for Abia and 106 for Imo). None was improperly filled or invalid; therefore, the 349 questionnaires returned representing $98.5 \%$ were used for analysis.

Table 1 - Respondents’ educational attainment

\begin{tabular}{|l|l|l|l|l|}
\hline Qualification & Abia & Imo & Total & \% Age \\
\hline WASC, GCE or equivalent & 55 & 39 & 94 & 27 \\
\hline Diploma or equivalent & 70 & 38 & 108 & 31 \\
\hline Degree & 100 & 25 & 125 & 36 \\
\hline $\begin{array}{l}\text { Post graduate certificate/ } \\
\text { higher degree }\end{array}$ & 18 & 4 & 22 & 6 \\
\hline Total & & & 349 & 100 \\
\hline
\end{tabular}

Source: Field survey, (2011)

The above table reveals that out of 349 respondents, 94 have school certificate or its, 108 have diploma, 125 respondents have degree and 22 respondents have postgraduate degrees or certificates.

Test of hypothesis 1: The hypothesis was tested with responses got from question 10 of the questionnaire. It asked. "Do you think that the governmental and nongovernmental mobilization agencies are doing enough work to raise the level of women participation in politics?”

To test the hypothesis Z- test was used.

$$
\begin{array}{lll}
Z & - & \text { Computed score } \\
X & -\quad & \text { Number of respondents supporting } \\
& \text { Ho (37) } \\
\mathrm{N} & \quad \text { - Sample size (354) } \\
\mathrm{P} & \text { - Probability of accepting Ho (80\%) or (.88) } \\
\mathrm{R} & \quad \text { - Level of significance (5\% or } 0.05)
\end{array}
$$




$\begin{array}{ll}Z & -\frac{X \quad n p}{n p ~(1-p)} \\ Z & \frac{-296-283.2}{283.2(.20)} \\ & =\frac{12.8}{56.64} \\ & =\frac{12.8}{7.5} \\ Z & =1.70 \\ Z x \quad= & 0.05=1.64\end{array}$

Decision Rule: Accept null hypothesis if $Z \geq Z x \quad 0.05$, and reject if $Z<Z x \quad 0.05$ Rejection of null hypothesis means acceptance of the alternative and vice versa. Since $\mathrm{Z}>$ Zx 0.05 , we accept the null hypothesis at $80 \%$ probability level. We therefore, conclude that governmental and non-governmental women mobilization agencies have not done enough work to raise the level of women participation in politics.

\section{Hypothesis Two:}

Ho: Political violence does not impair women’s involvement in political process in Abia and Imo States.

Hi: Political violence impairs women's involvement in political process in Abia and Imo States

The above stated hypothesis was tested with responses obtained from question No.30 of the questionnaire. It reads: "Do you consider violence a detrimental factor to women participation in the Nigerian political process?”.

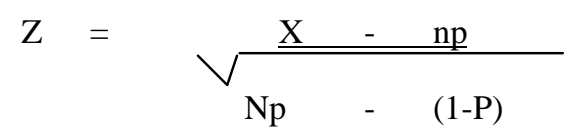

Where X - Respondents supporting Ho (317)

n $\quad$ - Sample size (354)

p - Probability of accepting Ho (.80)

$r \quad$ - Level of significance

I - Constant 
Substituting we have:

$317-354(.80)$

$354 \times .80(1-80)$

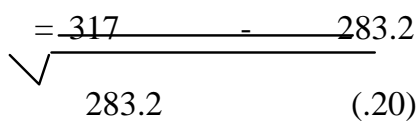

$=\underline{33.8}$

7.5

$\mathrm{Z}=4.50$

$\mathrm{ZX} 0.05=1.64$

Decision rule: Accept null hypothesis if $\mathrm{Z} \geq \mathrm{Zx} \times 0.05$ and reject if $\mathrm{Z}<\mathrm{Zx} 0.05$. Acceptance of the null implies rejection of the alternative and vice versa.

Decision: Since Z > Zx 0.05 at 80\% probability of acceptance, we accept the null Hypothesis and reject the alternative. We therefore conclude that the political violence In Nigeria has not favoured the participation of women in politics.

\section{Findings}

The study revealed the following:

(1) Incessant political thuggery and general violence have made female folks to dread politics in Nigeria. .

(2) The governmental and non-governmental agencies have not done enough work to sensitize women to get involved in politics

(3) Poverty has also been identified as a major constraint to women political \ participation

(4) Culture and traditional ethos also prevented the advancement of women in politics in Abia and Imo states of Nigeria. 


\section{Recommendations and Conclusion}

The following recommendations are proffered:

(1) Money politics should be abolished through legislation in Nigeria

(2) New laws should be enacted to address political thuggery and violence. Their implementation should be taken seriously to curb the high level of violence experienced in politics in Nigeria.

(3) Women mobilization agencies should wake up to do their work. Mobilization should be carried into the villages to sensitize all the women on the need to get involved in politics.

(4) Supporting the development of democracy means:

- defending the rights of women

- fighting corruption

- ensuring free and fair elections

- ensuring justice and fair play

(5) Women should be encouraged to take active part in politics through:

- joining political parties

- voting during election

- standing for election

- speak out in support of women's participation in politics anywhere the role of women in National development is being discussed.

We therefore conclude that unless women empowerment and mobilization programs are carefully articulated, executed and monitored their level of participation will remain low.

\section{References}

Ambe, P (2007) Why women should get involved in political process, Journal of Politics and Administration, 4(5) 21-30

Anderson, W (2008) What people look for in politics, International Journal of Government, 3(2) 40-49

Adefarasin, O (2009) Caribean women and Pan Africanism, African Journal of Political Science, 1(1) 55-61 
Bryan, M (2005) Women centered Politics: A new concept for exploring women Political perception, Groat Jeonna, M (Ed) Women Studies in the new millennium: Doing things differently: London: Macmillan Publishers

Brian, B (2005) Sociology: Themes and Perspectives, Slough: University Press

Chinsman, A (2005) Ethnic pluralism and democratic stability. Retrieved from

http//www.acadjournals.org/2005/index.htm

Chukwuemeka, E (2009) Democratisation in a praetorian polity; Development Question, Journal of the Management Sciences, 7(5) 35-44

Chukwuemeka, E (2009) Sources, Management and Uses of fund for women Welfare programmes, Umebali, E, Chukwuemeka, E, Njoku, A (Eds) Contemporary Issues in Local Government Administration and Rural Development in Nigeria, Enugu: Computer Edge Publishers

Dahl, R (1961) Who Governs? New Haven: Yale University Press

Ede, A (2008) The Committee system in local governments and grassroots democracy in Nigeria, Nigerian Journal of Public Administration and Local Government 2(5) 34-40

Eze, G (2009) Introduction to Political Science, Lagos: Vinez Publishers

Edu, C (2008) Poverty, microfinance and cooperative promotion in Nigeria, Nigerian Journal of Development and Management, 1(1) 35-42

Ezugwu, I (2004) Women and politics in the south east of Nigeria, Journal of Polic and Development Studies, 1(1) 29-38

Fubara, V (1995) A historical reconstruction of the role of women from early times, Women Revolt of 1929; Dike C (Ed.) :Lagos: Melag and Co.

Gorsuch, R (2000) How to achieve effective political participation, International Journal of Humanities, 3(4) 80-91

Hutington, S and Dominquez , J (1975) Political development ; Green Stain and Polsby (Eds), Handbook of Political Science, Vol. 3, Massachussets: Adison Wesley

Hills, U (2010) Man and politics, the contradictions. E-journal of Sociology, 3(3),45-60.Retrieved from http://ojs.lib.swin.edu.au/index.php/fdo

Harris, B (2006) Women and Politics, African Journal of Political Science andInternational Relations, 3(3) 25-37

Ibiam A (2005) Trends in Political Studies in Nigeria, Enugu: John Jacobs Classic Publishers Ike, H (2006) How to achieve a balanced socio-political development in South-SouthNigeria. Journal of Administration, 7(2) 55-62 
Kedly, C (2006) The role of African women: Past, present and future. Canadian Journal of African Studies, 2(1) 30-39

Malbraith, L (1999) Political Studies, New York: McGraw Hills

Mcphail, R (2009) Can women empowerment be attained in new states?, InternationalJournal of Sustainable Development, 4(2) 30-40

Norman, H. and Sidney, V (1975), Political participation in Greenstain F and Polsby N(Eds.) Handbook of Political Science Vol. 4, Massachusetts, Addison - Wesley

Nwankwo, G (2009) Issues in Nigerian Government, Enugu: HRV Publishers

Nonsen, J (2001) Women and Development in the third world, London: Routledge

Ntude, F (1999) Women contribution to the transition process: Issues and stratgegie. Udabah, S and Oji, O (Eds,) Transition in a Depressed Economy, Enugu: Auto Century Publishers

Njom, R (2008) Women in Agriculture: The Nigerian experience, Journal of LiberalStudies, 2(1) $34-43$

Nwosu, C (2007) Cooperative society: The role of women in the Eastern Nigeria, Journal of Policy and Development Studies, 2(2) 44-51

Ogbe, F (2008) Empowering women for National development: The Nigerian question.International Journal of Development Economics, 1(1) 20-31

Onah, F (1997) Sustainable development and women employment situation in Nigeria.Nigerian Journal of Public Administration and Local Government 6(2) 30-38

Ogbenna, P (2008) Women political participation in Umuahia South Local Government Area, ESUT Journal of Political Science 1(2) 35-49

Ogunnah, H (2006) Nigerian women mobilized, Enugu: Providence Press

Olori, E (2009) Democracy in Nigeria, Facts and Figures, Journal of Psychology, 4(2) 21-30

Oloaye, B (2008) Women: Key to development, African Development Review 1(1) 30-40

Ogu, N (2005) Empowerment of Nigerian women for political participation. Proceeding and paper delivered at a workshop on women political empowerment, Modotel Hotel, Enugu

Red, W (2004) Women in Business: Problems and prospects, Journal of Business Management, 1(1) 25-36

Thompson, W (2001) Political process in development nations, New Delhi: Vani Publishers

Ukor, C (2008) Women and Politics: The Nigerian Experience, Lagos: Mangroove Publishers

Ugochukwu, U (2009) Fundamentals of Public Administration in Nigeria; Enugu: HRV Publsihers 
Ugwueze, H (2010) The Nigerian Democratic Experiment: Problems and Prospects,Journal of Policy and Development Studies, 2(2) 23-38

Ugwuoke, B (2011) Political Science: A concise approach, Enugu: John Jacobs Classica Publishers

Uzochukwu, U (2008) Introduction to Business: The Nigerian Perspective, Enugu: HRV Publishders

Uche, B (1999) Ethnic pluralism and democratic stability: The basis of conflict and consensus. Oyediran , O (Ed.) Democratic Experiment in Nigeria, Lagos: Academy Press Ltd Ugwu, S (2001) Public and Urban Administration in Nigeria, Enugu: Echris Publishers

Ugwu, S (2007) Women marginalization in Nigeria, Journal of Social Development, 1(1) 23-32

Varma, S (1975) Modern Political Theory; Juniper: Vain Educational Books

Wambia, W (2008) Democratisation and women's political space in Nigeria: Lessons from the third Republic , Journal of Political Science, 1(2) 13-25 